\title{
Electrochemical Sensor for Hydroquinone based on Polyeugenol/PVA-Modified Graphite Electrode
}

\author{
Siti Marwati ${ }^{1,2, *}$, Wega Trisunaryanti ${ }^{1}$, Isana Supiah Yosephine Louise ${ }^{2}$, Dwi Siswanta ${ }^{1, *}$ \\ ${ }^{1}$ Department of Chemistry, Gadjah Mada University, Sekip Utara, Yogyakarta, 55281, Indonesia \\ ${ }^{2}$ Department of Chemistry Education, Yogyakarta States University, Karangmalang, Yogyakarta, \\ 55281, Indonesia \\ *E-mail: siti.marwati@mail.ugm.ac.id,dsiswanta@ugm.ac.id
}

doi: $10.20964 / 2020.11 .53$

Received: 21 July 2020 / Accepted: 5 September 2020 / Published: 30 September 2020

\begin{abstract}
The electrochemical sensor based on polyeugenol/polyvinyl alcohol-modified graphite electrode, i.e., GEPVAEu, was prepared for the determine the hydroquinone (HQ). The electrode was modified through an electropolymerization process. The modified electrode showed excellent performance for the HQ sensor in phosphate buffer solution (PBS) of $\mathrm{pH} 7.0$ by the cyclic voltammetry method. The impact of scan rates confirmeds that the redox electrochemical behavior of HQ was a diffusioncontrolled electrochemical process on the GEPVAEu electrode. The cyclic voltammetry results informed that GEPVAEu hads excessive electrocatalytic activity towards HQ oxidation if compared to the unmodified graphite electrode. The GEPVAEu electrode was able to determine the HQ concentration across two linear response stages from 3.67-103.27 and $140.90-482.11 \mu \mathrm{M}$ with the sensitivities of 4.13 and $1.02 \mu \mathrm{A} \mu \mathrm{M}^{-1}$, respectively. The LOD and LOQ values were $2.27 \mu \mathrm{M}$ and $6.87 \mu \mathrm{M}$, respectively, which were remarkable. Therefore, the GEPVAEu electrode has the potential to be used as an electrochemical sensor for the HQ.
\end{abstract}

Keywords: Hydroquinone, Electropolymerization, Polyeugenol, PVA, Graphite

\section{$\underline{\text { FULL TEXT }}$}

(C) 2020 The Authors. Published by ESG (www.electrochemsci.org). This article is an open access article distributed under the terms and conditions of the Creative Commons Attribution license (http://creativecommons.org/licenses/by/4.0/). 